\title{
PENGGUNAAN FITUR QUIS EDMODO UNTUK MENGUKUR KEMAMPUAN KOGNITIF MAHASISWA PENDIDIKAN GEOGRAFI PADA MATA KULIAH GEOGRAFI HEWAN DAN TUMBUHAN
}

\author{
Murjainah,S.Pd.,M.Pd. ${ }^{1)}$ \\ ${ }^{1)}$ Departemen Pendidikan Geografi, FKIP, Universitas PGRI Palembang. \\ Jl.Jendral A.Yani Lorong Gotong Royong, Plaju-kota Palembang \\ ${ }^{1)}$ Murjainah@gmail.com
}

\begin{abstract}
ABSTRAK
Penelitian ini dilaksanakan pada mahasiswa semester gazal tahun ajaran 2014/2015. Penelitian ini bertujuan untuk mengetahui penggunaan fitur quis Edmodo dalam mengukur kemampuan kognitif mahasiswa pendidikan Geografi pada mata kuliah Geografi Hewan dan Tumbuhan. Metode yang digunakan adalah metode penelitian deskriptif, yakni untuk mendeskripsikan /menjelaskan penggunaan fitur quis Edmodo untuk mengukur kemampuan kognitif mahasiswa pendidikan Geografi yang mengikuti mata kuliah Geografi Hewan dan Tumbuhan. Hasil penelitian menunjukkan bahwa: a) 89\% mahasiswa dapat terhubung koneksi internet dengan lancar (signal excelent);b) mahasiwa dapat melakukan registrasi Edmodo dengan sangat baik dengan persentase $86 \%$; c) mahasiswa dapat melakukan pengaturan di aplikasi Edmodo dikategorikan dengan baik dengan persentase $80 \%$ diantaranya mahasiswa dapat mengubah/ memasang foto profil dengan menggunakan ikon yang telah disediakan, mengubah informasi pribadi untuk menambahkan atau mengubah nama beserta alamat email dan mengubah kata sandi (password); d) mahasiswa dapat mengerjakan soal-soal di fitur Edmodo dengan sangat baik dengan persentase $84 \%$. Kemudian kemampuan kognitif mahasiswa setelah mengerjakan soal-soal, nilai yang diperoleh dari keseluruhan kelas dengan rata-rata nilai kelas adalah 70 dikelas V A, 80 dikelas V B dan 84 dikelas V C. Jadi, dapat disimpulkan bahwa penggunaan fitur quis Edmodo dapat digunakan mahasiswa dengan sangat baik meskipun ada beberapa hal yang harus diperhatikan, yaitu jaringan internet yang digunakan, kecepatan internet, dan penggunaan internet secara bersamaan pada satu website yang sama sehingga tidak mempengaruhi koneksi internet saat masuk/login aplikasi Edmodo dan saat mengerjakan soalsoal di fitur quis Edmodo.
\end{abstract}

\section{Kata Kunci/ Keyword : Edmodo, Kemampuan Kognitif}

\section{Pendahuluan}

Meningkatnya perkembangan teknologi saat ini sesungguhnya sangat membantu pengguna teknologi dalam memenuhi kebutuhannya, misalnya untuk memenuhi kebutuhan dalam berkomunikasi baik secara langsung via handphone maupun via internet. Komunikasi via internet saat ini dapat dilakukan oleh siapapun dan dimanapun bila pengguna telah terhubung dengan paket internet sehingga memudahkan user berkomunikasi secara online seperti jejaring media sosial facebook, twitter, serta media online yang digunakan sebagai pembelajaran. Saat ini media online tidak hanya digunakan untuk kesenangangan saja melainkan dapat juga digunakan dalam dunia pendidikan. Penelitian yang dilakukan oleh British Council pada tahun 2007 mengungkapkan bahwa 69\% pelajar diseluruh dunia mengatakan bahwa mereka belajar lebih efektif kalau bersosialisasi secara informal, dan pelajar yang mempunyai jaringan sosial yang kuat mempunyai performansi yang baik secara akademik. Selain itu, jejaring sosial online adalah alat komunikasi yang baik untuk membangun pengetahuan berdasarkan relasi sosial, percakapan, kerjasama dan berbagi pekerjaan (C. G. Arroyo (2011) ; Marzal, 2014). Hal tersebut sangat memungkinkan bagi pembelajar menggunakan media sosial online untuk mereka belajar dalam memperoleh pengetahuan dan mengukur sejauhmana kognitif mereka peroleh.

Salah satu media sosial yang dapat digunakan oleh para pengajar di banyak negara adalah Edmodo. Edmodo adalah sebuah website pembelajaran yang gratis dan aman yang dirancang oleh Jeff O'Hara dan Nick Borg pada tahun 2008 untuk guru, pelajar, orang tua , 
sekolah dan daerah, dan tersedia di www.edmodo.com. Website ini terlihat mirip dengan Facebook, tetapi website ini lebih private dan aman karena hanya mengizinkan teacher untuk membuat dan mengatur account, dan hanya mahasiswa yang mendapatkan kode group yang dapat mengakses dan bergabung ke grup tersebut (Marshal,2014).

Edmodo memberikan kemudahan pada user dalam hal ini pengajar membuat kelas secara virtual. Pengajar dapat memasukkan tugas, memberikan catatan membagikan materi belajar sehingga mahasiswa dapat mengerjakan tugas pada website tersebut dan memperoleh materi-materi perkuliahan. Pengajar juga dapat menentukan sendiri jenis soal yang diberikan baik berupa pilihan ganda, isian, menjodohkan, salah-benar maupun esay dengan menentukan skor soal sendiri jadi ketika mahasiswa mengerjakan soal tersebut sesuai waktu yang telah ditentukan dan dapat langsung mengetahui hasil evaluasi yang diperoleh tanpa harus menunggu hasilnya dari dosen. Artinya, mahasiswa dapat mengukur sendiri kemampuannya setelah menyelesaikan soal-soal dan memperoleh hasilnya. Dalam mengerjakannya pun dapat dilakukan dengan menggunakan laptop maupun smartphone.

Penggunaan Edmodo dalam perkuliahan dilakukan pada mata kuliah Geografi Hewan dan Tumbuhan untuk mengevaluasi kemampuan kognitif mahasiswa selama perkuliahan tersebut. Penggunaan ini digunakan dosen sebatas membuat quis dan mahasiswa mengerjakan soal yang telah di entry dosen pengampu karena dalam pelaksanaan kuliah dilakukan tatap muka setiap pertemuannya. Dalam menggunakannya, mahasiswa mengerjakan soal tersebut dengan menggunakan laptop maupun smartphone yang mempunyai fasilitas internet. Dalam pelaksanaannya terdapat kendala dalam melaksanakan evaluasi koginitif mahasiswa menggunakan edmodo dimana saat mahasiswa menjawab soal dikelas beberapa mahasiswa tidak dapat menyelesaikan soal secara sempurna dikarenakan saat menyelesaikan jawaban soal, edmodo eror sehingga nilai telah keluar sebelum selesai menjawab soal. Hal ini mengakibatkan mahasiswa harus mengulangi diwaktu yang lain dikarenakan kendala yang mereka hadapi. Karena itu, peneliti tertarik meneliti penggunaan fitur quis Edmodo untuk mengukur kemampuan kognitif mahasiswa.

Penelitian ini dilakukan bertujuan mengetahui penggunaan fitur quis Edmodo untuk mengukur kemampuan kognitif mahasiswa pada mata kuliah Geografi Hewan dan Tumbuhan Universitas PGRI Palembang.

\section{Hakikat Edmodo}

Edmodo merupakan sebuah situs pendidikan yang dikembangkan oleh Nicolas Borg dan Jeff O'Hara yang mengambil ide dari jaringan sosial dan cocok digunakan untuk pembelajaran di ruang kelas. Caulay (tanpa tahun) mengungkapkan bahwa "Edmodo is an educational website that takes the ideas of a social network and refines them and makes it appropriate for a classroom. Using Edmodo, students and teachers can reach out to one another and connect by sharing ideas, problems, and helpful tips. A teacher can assign and grade work on Edmodo; students can get help from the entire class on Edmodo. It is a safe environment. There is no bullying or inappropriate content, because the teacher can see everything that is posted on Edmodo. Also parents can join the class to bring a level of transparency that is difficult to achieve without technology. All in all Edmodo is a grat companion to just about any class."

Edmodo dapat membantu pengajar membangun sebuah kelas virtual sesuai dengan kondisi pembelajaran di dalam kelas, berdasarkan pembagian kelas nyata di sekolah, dimana dalam kelas tersebut terdapat penugasan, quiz dan pemberian nilai pada setiap akhir pembelajaran. Jadi, Edmodo dapat disimpulkan bahwa Edmodo merupakan suatu website pendidikan berbasis media sosial yang digunakan untuk pembelajaran. Edmodo memiliki kelebihan diantaranya memberikan kemudahan pada pengajar dalam memberikan tugas dengan meng-entry tugas, catatan, materi dan juga soal-soal; pengajar dapat dengan mudah mengetahui hasil belajar peserta didik; peserta didik dapat langsung mengetahui hasil belajar mereka secara langsung ketika mereka telah selesai mengerjakan soal.

2. Kemampuan Kognitif

Kemampuan berasal dari kata mampu yang berarti kuasa (bisa, sanggup) melakukan sesuatu, sedangkan kemampuan berarti kesanggupan, kecakapan, kekuatan (Kamus Besar Bahasa Indonesia, 1989). Menurut Sudijono (2001) ranah kognitif adalah ranah yang mencakup 
kegiatan mental (otak). Pengaturan aktivitas mental (otak) dengan menggunakan kaidah dan konsep yang telah dimiliki yang kemudian direpresentasikan melalui tanggapan, gagasan, atau lambang. Bloom dkk berpendapat bahwa taksonomi tujuan ranah kognitif meliputi enam jenjang proses berpikir yaitu: a) pengetahuan (knowledge); b) pemahaman (comprehension); c) aplikasi ( application) ; d) Analisis (analysis); e) Sintesis (synthesis) ; f) Evaluasi (evaluation) (Sudijono,2001).

Berdasarkan uraian tersebut, dapat disimpulkan bahwa kemampuan kognitif adalah kesanggupan individu yang dapat diamati melalui aktivitas mental (otak) dalam memperoleh pengetahuan melalui pengalaman sendiri. Dalam penelitian ini, mahasiswa memperoleh pengetahuan melalui tatap muka perkuliahan dan tugas-tugas yang diberikan oleh dosen pengampu. Kemudian, untuk mengukur kemampuan kognitif mahasiswa dilakukan tes dengan mengerjakan soal melalui fitur quis di Edmodo.

\section{Metode Penelitian}

Menurut Arikunto (2010), metode penelitian adalah cara yang dipakai dalam mengumpulkan data. Dalam penelitian ini, metode yang digunakan adalah metode penelitian deskriptif. Penelitian ini bertujuan untuk mendeskripsikan /menjelaskan penggunaan fitur quis Edmodo untuk mengukur kemampuan kognitif yang dilakukan pada mahasiswa semester lima yang terdiri dari kelas A, B dan C yang mengikuti mata kuliah GHT pada Program Studi Pendidikan.

Populasi dalam penelitian ini adalah seluruh mahasiswa semester $\mathrm{V}$ yang mengikuti mata kuliah Geografi Hewan dan Tumbuhan yang menggunakan fitur quis Edmodo yang berjumlah 115 orang yang terdiri dari tiga kelas. Sampel yang digunakan dalam penelitian ini adalah Random Sampling. Teknik pengambilan sampel dilakukan dengan menggunakan persentase yakni mengambil sampel $30 \%$ sehingga jumlah sampel yang digunakan adalah 34,5 orang dibulatkkan menjadi 34 orang.

Teknik pengumpulan data dalam penelitian ini, yaitu dengan menggunakan a) dokumentasi, ditujukan untuk bukti otentik dalam penelitian yang terdiri dari data mahasiswa, foto-foto penggunaan Edmodo; b) angket, angket tertutup. Angket tertutup merupakan sejumlah pertanyaan tertulis yang telah disediakan jawabannya sehingga responden tinggal memilih jawaban sesuai kondisi responden. Pilihan jawaban disediakan dalam bentuk pilihan ya dan tidak. Setelah dilakukan penghitungan kemudian peneliti menginterpretasi skor penilaian angket dengan kriteria; (0\%) tidak baik, (21\%-40\%) kurang baik, (41\%-60\%) cukup baik, $(61 \%-80 \%)$ baik, (81\%-100\%) sangat baik. Setelah angket dikumpulkan dan ditabulasi selanjutnya peneliti melakukan penghitungan hasil angket dengan menggunakan rumus persentase, yaitu $P=N / F$ $\mathrm{x} 100 \%$. Dimana $\mathrm{P}=$ angka persentase; $\mathrm{F}=$ frekuensi yang sedang dicari persentasenya; $\mathrm{N}=$ number of Cases (jumlah frekuensi/banyaknya individu); $100 \%$ bilangan tetap (kostanta); c) Tes dilakukan bertujuan untuk mengukur kemampuan kognitif mahasiswa dalam mengerjakan soasoal yang telah di-input-kan ke dalam fitur quis Edmodo dan diberikan kepada kelas A,B dan C dengan soal sebanyak 45 soal yang terdiri dari pilihan ganda, isian titik-titik, menjodohkan dan esay.

\section{Hasil Dan Pembahasan}

\section{Hasil Penelitian}

Sebelum melaksanakan penelitian, mahasiswa diintruksikan untuk melakukan registrasi dan pengaturan di Edmodo yang sebelumnya juga diberikan arahan dalam mengakses edmodo dan peneliti melakukan beberapa kali pertemuan tatap muka perkuliahan dengan kegiatan penyampaian materi perkuliahan, diskusi dan tanya jawab serta mengerjakan soal-soal latihan dan tugas mandiri di rumah, Kemudian, pada pertemuan ke-8 peneliti melakukan evaluasi kemampuan kognitif mahasiswa dengan memberikan tugas kepada mahasiswa untuk menjawab soal-soal yang terdapat di aplikasi Edmodo yang sebelumnya peneliti meng-entry soal-soal berupa soal pilihan ganda dan isian singkat. Setelah mereka selesai menjawab soal quis di aplikasi Edmodo, selanjutnya peneliti memberikan angket kepada mahasiswa dan memberikan kesempatan kepada mahasiswa untuk menjawab pertanyaan angket yang telah tersedia sesuai 
dengan kondisi yang dialami mahasiswa dalam menggunakan aplikasi Edmodo. Aktivitas mahasiswa menggunakan Fitur Quis Edmodo dapat dilihat pada gambar 1 berikut ini.

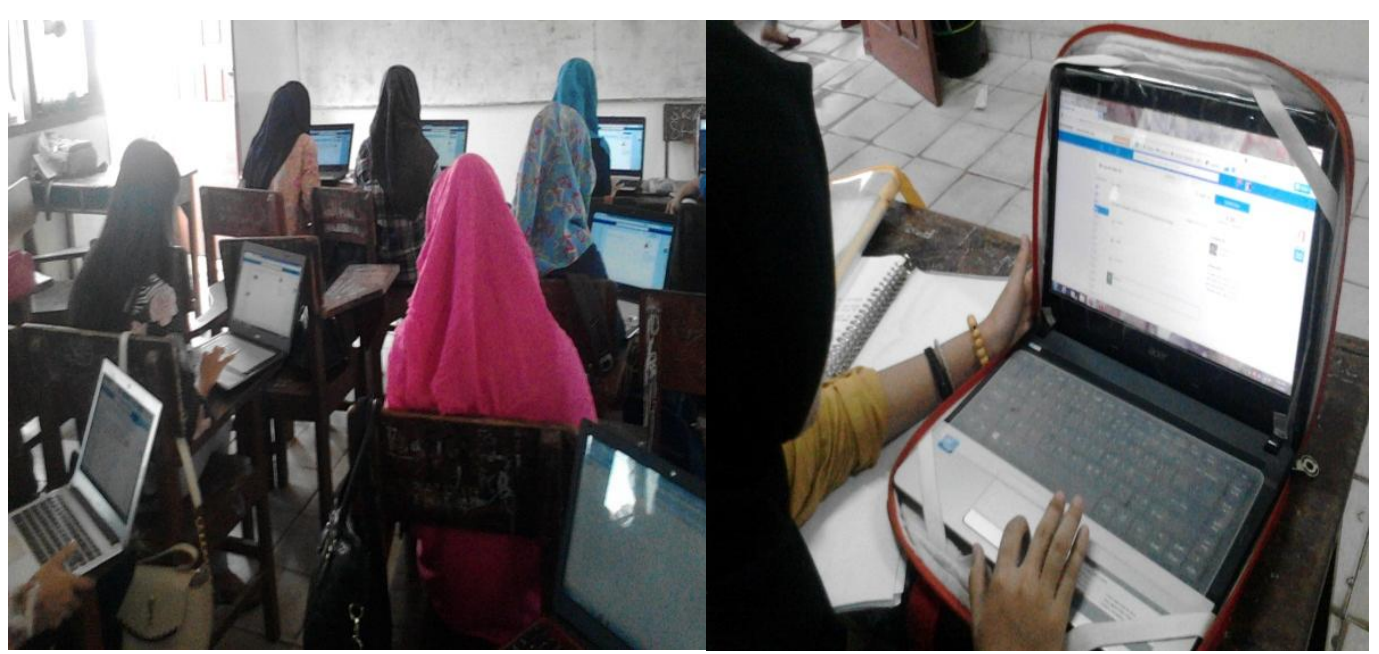

Gambar 1. Aktivitas mahasiswa menggunakan fitur quis Edmodo.

Setelah semua angket selesai diberikan secara acak kepada mahasiswa dari ketiga kelas. Selanjutnya, peneliti mengumpulkan, mengecek angket yang telah terisi apakah angket telah diisi semua dengan lengkap atau sebaliknya dan memilah-milah angket berdasarkan hal yang pokok dan penting serta mengklasifikasikannya sesuai dengan fokus yang ada pada masalah dalam penelitian ini. Kemudian, angket di tabulasi dengan menggunakan Ms.Excel dan dilakukan penghitungan dengan menggunakan rumus persentase. Penggunaan fitur quis Edmodo untuk mengukur kemampuan kognitif mahasiswa dapat dilihat pada gambar 2 berikut ini.

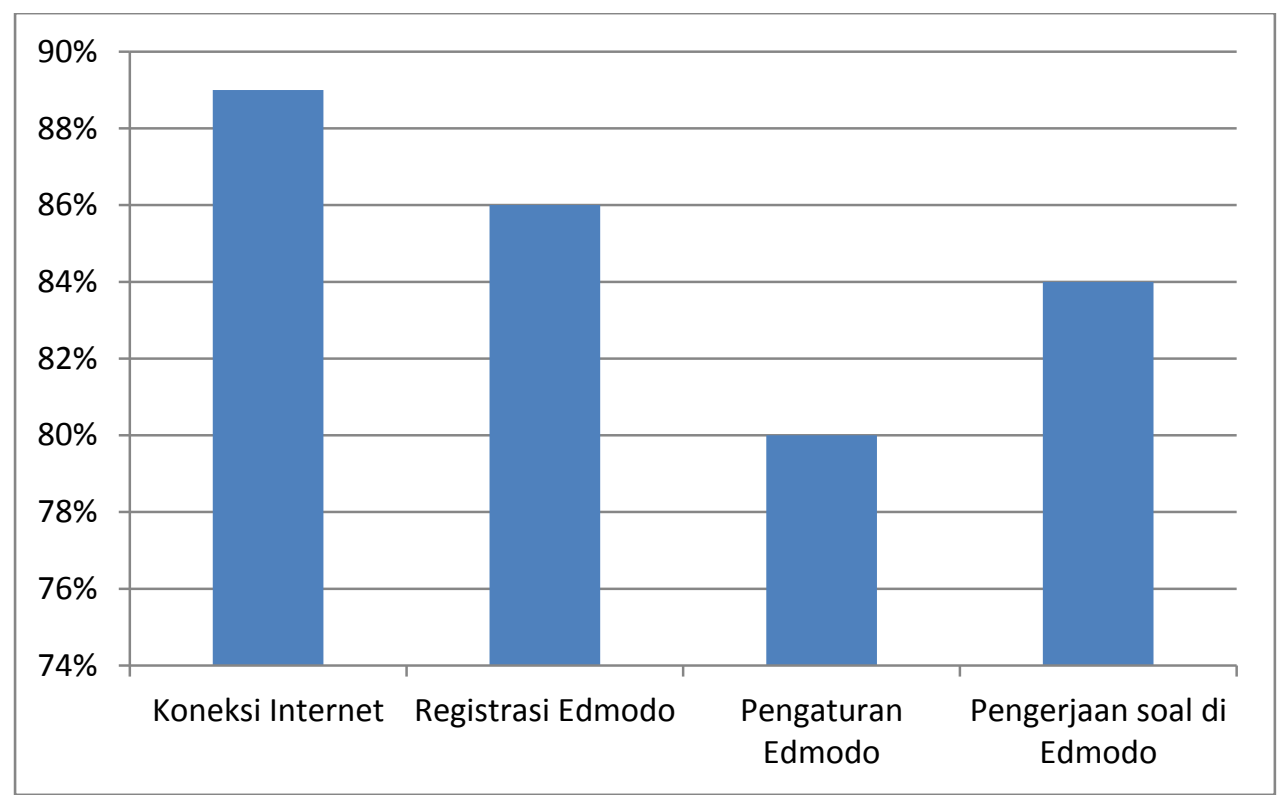

Gambar 2. Penggunaan Fitur Quis Edmodo

Koneksi Internet dikategorikan sangat baik dimana terdapat $89 \%$ mahasiswa yang terhubung internet dan dapat membuka www.edmodo.com, $11 \%$ tidak dapat membuka situs tersebut. Kemudian, Rerata mahasiswa yang dapat melakukan registrasi Edmodo terdapat $86 \%$ diantaranya a) $82 \%$ mahasiswa yang dapat melakukan regitrasi account di Edmodo sebagai siswa dengan mudah. Sedangkan, sisanya yakni $12 \%$ diketahui bahwa mengalami kendala belum memiliki email sebab sebelum melakukan registrasi diharuskan memiliki email, ada juga yang memiliki email tetapi lupa password; b) $83 \%$ mahasiswa mendapatkan konfirmasi registrasi di email yang telah didaftarkan, sebalingknya 17\% mahasiswa tidak mendapatkan konfirmasi registrasi di email yang telah didaftarkan; c) $89 \%$ mahasiswa dapat bergabung dengan Edmodo atau masuk ke beranda Edmodo setelah melakukan registrasi, $11 \%$ mahasiswa 
lainnya tidak dapat bergabung ke Edmodo atau masuk ke beranda Edmodo setelah melakukan registrasi; d) terdapat $90 \%$ mahasiswa dapat masuk ke dalam grup Edmodo setelah registrasi dengan memasukkan kode grup.

Selajutnya, rerata penggunaan edmodo dalam pengaturannya terdapat $80 \%$ dapat melakukan pengaturan Edmodo, diantaranya; a) 83\% mahasiswa dapat mengubah/ memasang foto profil dengan menggunakan ikon yang telah disediakan dan $17 \%$ tidak dapat mengubah/ memasang foto profil; b) $78 \%$ mahasiswa dapat mengubah informasi pribadi untuk menambahkan atau mengubah nama beserta alamat email sebaliknya $22 \%$ mahasiswa tidak dapat mengubah informasi pribadi; c) 79\% mahasiswa dapat mengubah kata sandi (password), sedangkan $21 \%$ tidak dapat melakukan pengaturan Edmodo dikarenakan mahasiswa masih bingung dan belum familiar menggunakan Edmodo sebagai salah satu langkah sebelum mengerjakan soal- soal di Edmodo.

Rerata penggunaan Edmodo dalam mengerjakan soal menggunakan fitur quis Edmodo terdapat $84 \%$ mahasiswa. Hal ini dilihat dari kemampuan mahasiswa dalam mengerjakan quis di Edmodo yang terdiri dari; 1) $91 \%$ mahasiswa dapat masuk ke fitur quis di Edmodo, selebihnya yakni $9 \%$ tidak dapat masuk ke fitur quis Edmodo, ini dikarenakan mahasiswa lupa dengan password yang mereka registrasi ke Edmodo; 2) $89 \%$ mahasiswa yang dapat mengerjakan soal quis pilihan ganda di Edmodo dengan meng-entry pilihan jawaban yang telah disediakan dan yang tidak dapat mengerjakan soal quis pilihan ganda di Edmodo terdapat 11\% ; 3) mahasiswa yang dapat mengerjakan soal quis fill in the blank di Edmodo dengan mengentry jawaban sebanyak $83 \%$ dan terdapat $17 \%$ mahasiswa tidak dapat mengerjakan soal quis fill in the blank; 4) mahasiswa dapat mengerjakan soal quis menjodohkan dengan menarik jawaban soal pada soal yang telah disediakan terdapat $85 \%$ dan selebihnya $15 \%$ tidak dapat mengerjakan soal menjodohkan dengan menarik jawaban soal yang telah disediakan ; 5) mahasiswa yang dapat mengerjakan soal Esay dengan mengentri jawaban terdapat $80 \%$ dan

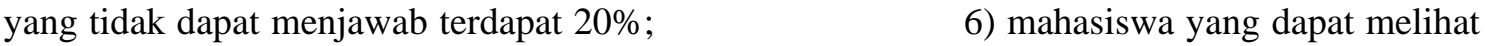
masing-masing skor soal quis yang telah disediakan terdapat $89 \%$ dan selebihnya yakni $11 \%$ tidak dapat melihat masing-masing skor soal quis yang telah disediakan; 7) mahasiswa yang dapat menyelesaikan soal quis di Edmodo dengan lancar tanpa mengalami kendala apapun (eror program) terdapat $71 \%$ dan mahasiswa yang tidak dapat menyelesaikan soal quis di Edmodo dengan lancar terdapat $29 \%$; 8) mahasiswa yang dapat mengetahui skor nilai terdapat $91 \%$ dan 9\% mahasiswa tidak dapat mengetahui skor nilai karena ketika menyelesaikan soal mengalami eror program yakni saat mengerjakan soal aplikasi terhenti dan langsung masuk ke beranda user dan ada juga koneksi internet terputus; 9) mahasiswa yang dapat menyelesaikan soal sesuai dengan waktu yang telah ditentukan terdapat $85 \%$ dan $15 \%$ mahasiswa tidak dapat menyelesaikan soal tepat waktu. 10) mahasiswa yang mendapatkan skor nilai tinggi setelah mengerjakan soal quis di Edmodo terdapat $77 \%$ dan yang tidak mendapatkan skor nilai tinggi setelah mengerjakan soal quis di Edmodo terdapat 23\%; 11) mahasiswa yang dapat mengetahui hasil belajar (skor nilai) sendiri dan teman yang lainnya di fitur progress Edmodo terdapat $81 \%$ dan 19\% mahasiswa tidak dapat mengetahui hasil belajar (skor nilai) sendiri dan teman yang lainnya di fitur progress Edmodo. Untuk lebih jelasnya dapat dilihat pada gambar 3 berikut ini. 


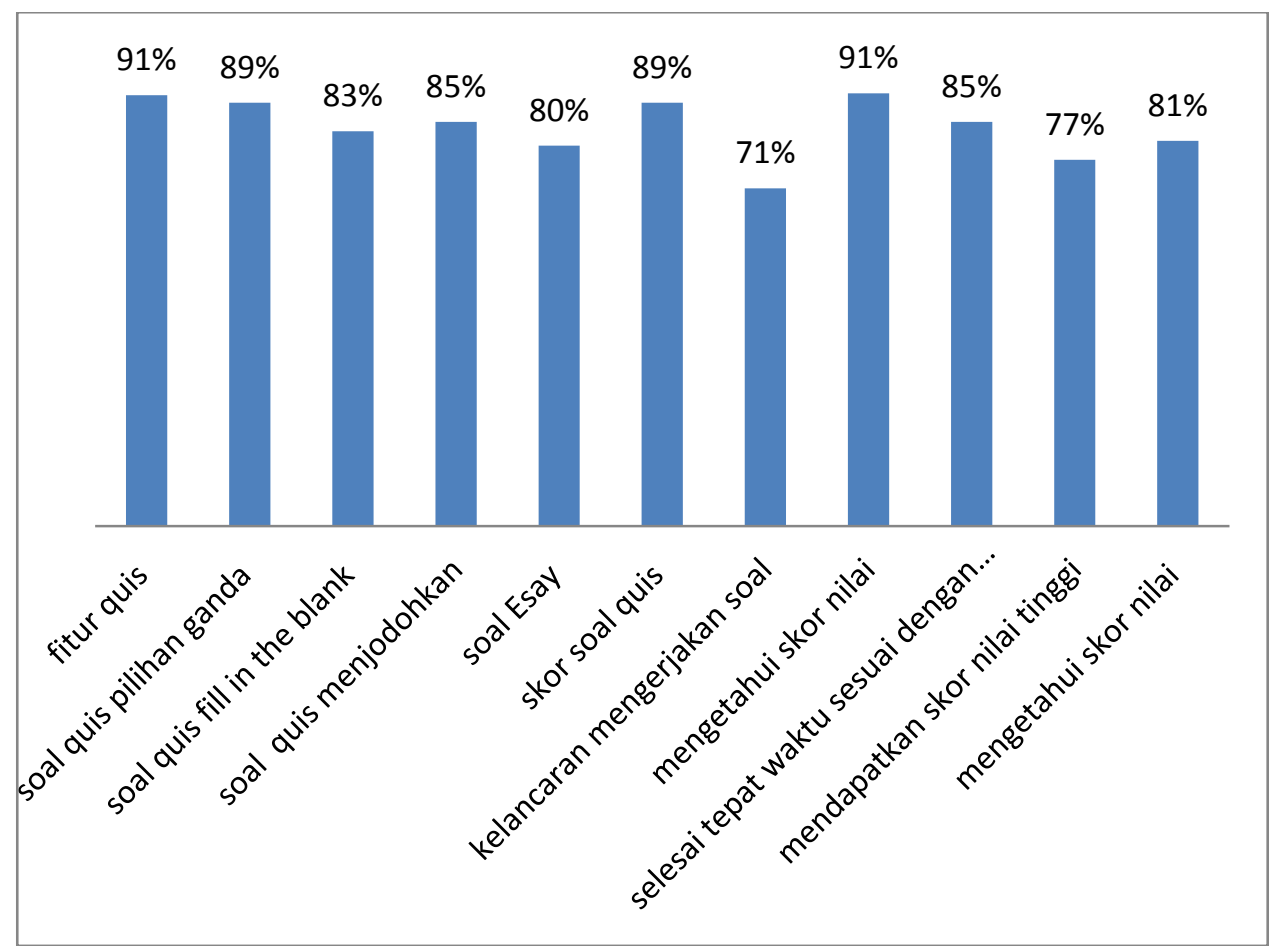

Gambar 3. Pengerjaan Quis di Edmodo

Dilihat dari hasil kemampuan kognitif mahasiswa dalam mengerjakan soal-soal dengan menggunakan fitur quis pada aplikasi Edmodo menunjukkan rata-rata nilai yang diperoleh adalah 70 dikelas V A, 80 dikelas V B dan 84 dikelas V C. Meskipun terdapat beberapa mahasiswa mengulang mengerjakan soal hal ini dikarenakan mengalami sinyal koneksi yang buruk bahkan terputus koneksi internet dan juga penggunaan provider yang berbeda-beda sehingga mereka harus mengulang mengerjakan quis di fitur Edmodo. Jadi, dapat disimpulkan bahwa penggunaan fitur quis Edmodo dapat digunakan dengan lancar jika koneksi internet lancar/exxcelent dan tidak dilaksanakan secara bersamaan di dalam kelas, pada saat mengerjakan soal di fitur quis Edmodo di dalam satu kelas yang terdiri dari 35-40 mahasiswa memakai layanan internet secara bersamaan maka mempengaruhi kecepatan penggunaan internet dan mengakibatkan kecepatan dalam penggunaan Edmodo terhambat, sedangkan layanan internet yang digunakan berupa layanan nirkabel yang bersumber dari jaringan GSM yang di-hotspot-kan kepada mahasiswa dan juga banyak jaringan GSM dari berbagai provider di Universitas PGRI.

\section{Pembahasan}

Edmodo merupakan salah satu website jejaring sosial yang hampir sama seperti Fecebook namun yang membedakannya adalah fitur yang terdapat pada beranda Edmodo yang dapat digunakan oleh guru dan siswa dalam proses pembelajaran sebagai salah satu metode dalam pembelajaran. Penggunaan Edmodo tidak hanya dapat digunakan pada tingkat sekolah tetapi juga dapat digunakan oleh pendidikan tinggi dalam proses pembelajaran sebab Edmodo juga mengakomodasi proses pembelajaran jarak jauh karena dapat berkomunikasi satu sama lain seperti halnya facebook. Selain itu, didalamnya terdapat fitur untuk memasukkan tugas, catatan, bahkan soal-soal untuk mengukur kemampuan pembelajar sehingga mereka dapat mengetahui dan mengukur kemampuan mereka setelah mengerjakan tugas melalui Edmodo dan pendidik dapat memasukkan berbagai tipe soal dan menentukan skor soal serta siswa dapat mengetahui langsung hasil setelah mereka selesai mengerjakan soal tersebut.

Dalam penelitian ini, peneliti menggunakan Edmodo pada mata kuliah Geografi Hewan dan Tumbuhan untuk mengukur kemampuan kognitif mahasiswa setelah mengikuti beberapa kali pertemuan tatap muka perkuliahan sebab dalam proses perkuliahan dilaksanakan di ruang kelas. Penelitian ini, hanya pada penggunaan fitur quis di Edmodo yakni meng-entry soal-soal dengan tipe soal pilihan ganda, fill in the blank, menjodohkan, dan esay dan menentukan skor nilai. Soal yang di-entry sebanyak 45 soal dengan skor keseluruhan 100 . 
Berdasarkan hasil angket menunjukkan bahwa penggunaan fitur quis Edmodo dilihat dari koneksi internet dikategorikan sangat baik yakni 89\% mahasiswa dapat terhubung koneksi internet dengan lancar (signal excelent) walaupun ada beberapa laptop mahasiswa yang eror yakni wifi tidak muncul di device laptop setelah ditambatkan hot spot mahasiswa, koneksi internetnya lambat sehingga membutuhkan waktu yang lama untuk membuka website Edmodo. Sebab kecepatan penggunaan internet bergantung pada banyaknya pengguna website secara bersamaan, misalnya sebuah operator menawarkan koneksi cepat melalui jaringan GSM dengan kualitas HSDPA, berarti kecepatan maksimum untuk mengunduh data adalah 3,6 MB per detik atau $3600 \mathrm{~KB}$ per detik. Jadi, jika dipakai secara bersamaan maka akan mempengaruhi kecepatan penggunaan internet. Kemudian, agar dapat menggunakan Edmodo mahasiswa harus melakukan registrasi Edmodo karena ini sebagai awal dari penggunaan Edmodo.Dilihat dari hasil angket dan juga pengamatan kepada mahasiswa dalam menggunakan Edmodo menunjukkan bahwa mahasiwa dapat melakukan registrasi Edmodo dengan sangat baik dengan persentase $86 \%$ walaupun ada beberapa catatan bagi mahasiswa untuk mengingat email yang digunakan untuk registrasi Edmodo beserta password-nya.

Selanjutnya, penggunaan Edmodo pada pengaturan Edmodo secara keseluruhan menunjukkan bahwa mahasiswa dapat melakukan pengaturan di aplikasi Edmodo dikategorikan dengan baik dengan persentase $80 \%$ diantaranya mahasiswa dapat mengubah/ memasang foto profil dengan menggunakan ikon yang telah disediakan, mengubah informasi pribadi untuk menambahkan atau mengubah nama beserta alamat email dan mengubah kata sandi (password). Meskipun begitu, dapat dikatakan terdapat beberapa mahasiswa yang belum dapat mengubah foto profil, mengubah informasi pribadi dan mengubah kata sandi hal ini dikarenakan mahasiswa masih bingung dan belum familiar menggunakan Edmodo.

Dalam penggunaan Edmodo, peneliti menekankan pada penggunaan fitur quiz Edmodo yang digunakan untuk mengukur kemampuan kognitif mahasiswa yakni mengerjakan soal-soal pada materi mata kuliah Geografi Hewan dan Tumbuhan yang telah di-entry dosen pengampu mata kuliah. Dilihat dari hasil angket dan juga observasi kepada mahasiswa menunjukkan bahwa mahasiswa dapat mengerjakan soal-soal di fitur Edmodo dengan sangat baik dengan persentase $84 \%$ diantaranya mahasiswa dapat masuk ke fitur quis di Edmodo, mengerjakan soal quis pilihan ganda di Edmodo dengan meng-entry pilihan jawaban yang telah, mengerjakan soal quis fill in the blank di Edmodo dengan meng-entry jawaban, dapat mengerjakan soal quis menjodohkan dengan menarik jawaban soal pada soal yang telah disediakan, dapat mengerjakan soal Esay dengan mengentri jawaban, dapat melihat masing-masing skor soal quis yang telah disediakan, dapat menyelesaikan soal quis di Edmodo dengan lancar tanpa mengalami kendala apapun (eror program), dapat mengetahui skor, dapat menyelesaikan soal sesuai dengan waktu yang telah ditentukan terdapat $85 \%$, mendapatkan skor nilai tinggi setelah mengerjakan soal quis di Edmodo, dapat mengetahui hasil belajar (skor nilai) sendiri dan teman yang lainnya di fitur progress Edmodo. Kemudian, kemampuan kognitif mahasiswa setelah mengerjakan soal-soal, nilai yang diperoleh dari keseluruhan kelas dengan rata-rata nilai kelas adalah 70 dikelas V A, 80 dikelas V B dan 84 dikelas V C. Meskipun begitu, ada beberapa mahasiswa pada saat mengerjakan soal di fitur quis Edmodo di dalam satu kelas yang terdiri dari 35-40 mahasiswa memakai layanan internet secara bersamaan maka mempengaruhi kecepatan penggunaan internet dan mengakibatkan kecepatan dalam penggunaan Edmodo terhambat, sedangkan layanan internet yang digunakan berupa layanan nirkabel yang bersumber dari jaringan GSM yang di-hotspot-kan kepada mahasiswa dan juga banyak jaringan GSM dari berbagai provider di Universitas PGRI.

Berdasarkan uraian tersebut, maka dapat disimpulkan bahwa penggunaan fitur quis Edmodo dapat digunakan mahasiswa dengan sangat baik tetapi ada beberapa hal yang harus diperhatikan, yaitu jaringan internet yang digunakan, kecepatan internet, dan penggunaan internet secara bersamaan pada satu website yang sama sehingga tidak mempengaruhi koneksi internet saat masuk/login aplikasi Edmodo dan saat mengerjakan soal-soal di fitur quis Edmodo. 


\section{Kesimpulan Dan Saran}

1. Kesimpulan

Penggunaan fitur quis Edmodo dilakukan untuk mengukur kemampuan kognitif mahasiswa pada mata kuliah Geografi Hewan dan Tumbuhan Program Studi Pendidikan Geografi. Sebelum menggunakan fitur quis Edmodo, mahasiswa melakukan mengaktifkan koneksi internet; melakukan registrasi Edmodo; pengaturan Edmodo dan mengerjakan soal-soal di fitur quis Edmodo. Hasil penelitian menunjukkan bahwa secara keseluruhan penggunaan fitur quis Edmodo dapat dikategorikan sangat baik karena sebagian besar mahasiswa dapat terhubung koneksi internet dengan lancar (signal excelent; mahasiwa dapat melakukan registrasi Edmodo dengan sangat baik; mahasiswa dapat melakukan pengaturan di aplikasi Edmodo dikategorikan dengan baik; mahasiswa dapat mengerjakan soal-soal di fitur Edmodo dengan sangat baik karena terlihat dari hasil mahasiswa setelah mengerjakan soal-soal, nilai yang diperoleh dari keseluruhan kelas dengan rata-rata nilai kelas adalah 70 dikelas $\mathrm{V} \mathrm{A}, 80$ dikelas $\mathrm{V}$ B dan 84 dikelas V C.

2. Saran

Saran dalam penelitian ini, yaitu; 1) mahasiswa dapat menjadikan Edmodo sebagai alternatif pembelajaran mandiri; 2) dosen dapat menjadikan sumber dosen sebagai alternatif lain aktivitas perkuliahan; 3) program Studi dapat menambah khasanah/ kajian/ sumber informasi untuk penelitian lain; 4) peneliti lain dapat dijadikan sebagai penelitian lain sejenis ataupun penelitian lebih lanjut.

\section{Daftar Pustaka}

1989. Kamus Besar Bahasa Indonesia Edisi Kedua. 1989. Balai Pustaka. Jakarta. Arikunto, S. 2010. Prosedur Penelitian Suatu pendekatan praktik. Jakarta: PT Rineka Cipta

Caulay, Patrick. Tanpa Tahun. A guide to explain it all edmodo. (online). (http://www.csub.edu/ tfernandez_ulloa/Edmodo\%20User\%20guide.pdf, diunduh tanggal 8 Agustus 2014).

Marzal, J. 2014. Studi Penggunaan Jejaring Sosial Edmodo Sebagai Media E-Learning Oleh Dosen Senior Yang Tidak Terbiasa Bekerja Dengan Komputer. Edumatical Journal Pendidikan Matematika Vol.4 No.1. (online). (http://onlinejournal.unja.ac.id/index.php/edumatica /article /view/1587 diakses tanggal 5 Agustus 2014).

Sudijono, Anas. 2001. Pengantar Evaluasi Pendidikan. Jakarta: PT. Raja Grafindo Persada 